\title{
Atendimento odontológico em UTI's na presença de COVID-19
}

\author{
Aline Batista Gonçalves Franco' \\ Amanda Gonçalves Franco ${ }^{2}$ \\ Geraldo Alberto Pinheiro de Carvalho' \\ Sérgio Candido Dias ${ }^{1}$ \\ Caio Marques Martins' \\ Elimario Venturin Ramos ${ }^{1}$ \\ Fabiano Perez ${ }^{1}$ \\ Silvio Mecca Junior ${ }^{1}$
}

A cavidade oral é considerada, por especialistas, abertura para a entrada de muitos microorganismos. Isso acontece por apresentar características bastante propícias para o desenvolvimento dos mesmos, como a temperatura e a umidade, que facilitam a sua permanência. Em vista disso, há uma enorme preocupação dos cirurgiões dentistas, médicos e enfermeiros em relação a saúde bucal dos pacientes, principalmente nas unidades de terapia intensiva (UTI's), onde os pacientes se encontram mais vulneráveis.

Microrganismos provenientes da boca podem causar infecções generalizadas, como a pneumonia e a sepse, ambas doenças complexas e que podem causar danos mais graves ao organismo. Pacientes acamados em UTI's devem receber cuidados com a saúde bucal visando limitar a disseminação desses microrganismos. Ou seja, o tratamento tem como objetivo impedir que os microorganismos se disseminem da cavidade oral para outras regiões, como o trato respiratório. Sabese que pneumonias associadas à ventilação mecânica podem retardar a recuperação do paciente. Portanto, muitas destas complicações podem ser evitadas caso o tratamento na UTI esteja vinculado à um atendimento odontológico.
Esses atendimentos são feitos nas próprias unidades de terapia intensiva e realizados por profissionais que atuam na área, os cirurgiões dentistas. Eles trabalham sempre com equipes multidisciplinares, composta por médicos, fonoaudiólogos, fisioterapeutas, e enfermeiros, para ajudar no acompanhamento do tratamento. Dessa forma, o atendimento odontológico não apenas previne as infecções bucais, assim como visa limitar que as doenças dos pacientes acamados evoluam para quadros mais graves ou o óbito.

O novo tipo de coronavírus, identificado no fim de 2019 na China, o COVID-19, pertence a uma grande família viral que atinge o sistema respiratório. Portanto, vê-se assim a necessidade de cirurgiões dentistas não apenas para realizar os procedimentos odontológicos comuns nas UTI's, mas também para combaterem a disseminação desse vírus pelas vias aéreas.

Segundo a ANVISA (2020, p. 22), o protocolo de Higiene Bucal na UTI frente ao coronavírus é:

- Pacientes com risco descartado para COVID-19: Manter Protocolo Operacional Padrão (POP) de higiene bucal com clorexidina a 0,12\%.; - Pacientes confirmados ou com suspeita de COVID-19 que estiverem submetidos a traqueostomia ou intubação orotraqueal: -

\footnotetext{
${ }^{1}$ Faculdade São Leopoldo Mandic, Curso de Medicina. Rua José Rocha Junqueira, 13, Swift, 13045-755, Campinas, SP, Brasil Correspondência para / Correspondence to: AG FRANCO. E-mail: <aalinebgfranco@yahoo.com>.

${ }^{2}$ Universidade de Itaúna, Faculdade de Odontologia. Itaúna, MG, Brasil.

$\triangle \otimes \square \otimes \square$

Como citar este artigo / How to cite this article

Franco ABG, Franco AG, Carvalho GAP, Dias SC, Martins CM, Ramos EV, et al. Atendimento odontológico em UTI's na presença de COVID-19. InterAm J Med Health 2020;3:e202003004
} 
- Aplicar gaze ou swab bucal embebidos em 15ml de peróxido de hidrogênio a $1 \%$ ou povidona a 0,2\% por 1 minuto, 2 vezes ao dia previamente a higiene bucal com clorexidina visando a redução da carga viral. - Utilizar clorexidina 0,12\% embebida em gaze ou swab bucal, de 12 em 12 horas visando a prevenção de Pneumonia Associada a Ventilação Mecânica - PAV desde o momento da intubação orotraqueal.; - Pacientes confirmados ou com suspeita de COVID-19 conscientes orientados e em ar ambiente: Realizar bochecho de $15 \mathrm{ml}$ de peróxido de hidrogênio a $1 \%$ ou povidona a $0,2 \%$ por um minuto, 1 vez ao dia. - Manter POP de higiene bucal com clorexidina a $0,12 \%$.

Quanto à necessidade de intervenção odontológica em UTI's frente ao coronavírus, as recomendações são:

- Pacientes com suspeita ou confirmados de infecção pelo novo coronavírus: não realizar exame intra-oral, a não ser que o paciente apresente sinais e sintomas de alterações bucais que provoquem implicações sistêmicas ou a pedido médico. Caso seja preciso a abordagem odontológica, utilizar solução de peróxido de hidrogênio a $1 \%$ durante 1 minuto antes da realização do exame intra-oral e antes de qualquer procedimento odontológico. Realizar o exame intra-oral e procedimentos odontológicos utilizando luvas, gorro, avental impermeável, máscara N95 (PFF2) ou equivalente e protetor facial (face shield).

- Pacientes sem a suspeita da presença de COVID-19: Promover o exame intra oral e os procedimentos odontológicos utilizando os mesmos equipamentos de proteção individual citados para os casos suspeitos ou confirmados, pois mesmo assintomática a pessoa pode ser portadora do vírus. Somente em caso de urgência, realizar procedimentos odontológicos iinvasivos. Antes do exame intra-oral ou de procedimento odontológico, utilizar solução de peróxido de hidrogênio a $1 \%$ durante 1 minuto.

Para o atendimento de pacientes críticos em UTI, além dos cuidados já citados, recomenda-se: não usar alta ou baixa rotação e spray de água em procedimentos. Caso haja necessidade absoluta deste uso, esse procedimento deve ser feito em centro cirúrgicos, utilizando isolamento absoluto, protetores facias e máscaras N95; utilizar, sempre que possível, instrumentos manuais para minimizar a geração de aerossóis; utilizar aspirador descartável durante todo o atendimento; Utilizar suturas absorvíveis; evitar radiografias intra-orais.

Os cirurgiões dentistas que trabalham nas UTI's, assim como os outros profissionais da área da saúde que estão em contato com o paciente contaminado pelo coronavírus, se encontram bastante susceptíveis à contaminação. Isso acontece pelo fato de trabalharem em contato próximo com os pacientes e fluidos corporais, os principais transmissores da doença. Sendo assim, é essencial que eles tomem todas as medidas preventivas preconizadas nas UTI's para diminuir o risco de contaminação e de transmissão. Dessa forma, haverá mais segurança para a equipe, o paciente e o próprio profissional.

\section{REFERÊNCIAS}

1 Brasil. Ministério da saúde. Agencia Nacional de Vigilância Sanitária. Resolução RDC n. 04, de 21 de março de 2020. Orientações para serviços de saúde: medidas de prevenção e controle que devem ser adotadas durante a assistência aos casos suspeitos ou confirmados de infecção pelo novo coronavírus (sars-cov-2) [online]. Disponível em: http://portal.anvisa.gov.br/documents/33852/271858/ NOTA + T \% C $3 \% 89$ CNICA + N \% C $2 \% B A+05-$ 2020+GVIMS-GGTES-ANVISA+-+ORIENTA \%C3\%87\%C $3 \% 95 E S+P A R A+A+P R E V E N \% C 3 \% 87 \% C 3 \% 830+E+O+$ CONTROLE+DE+INFEC \% C $3 \% 87 \%$ C $3 \% 95 E S+P E L O+N O$ VO+CORONAV\% C3\% 8DRUS+EM+INSTITUI\%C3\%87 \% C3\% 95ES+DE+LONGA+PERMAN\% C3\% 8ANCIA+P ARA+IDOSOS\%28ILPI\%29/8dcf5820-fe26-49dd-adf91 cee 4 e6d3096

Assis C. Atendimento Odontológico nas UTIs. Rev Bras Odontol. 2012;69(1) [citado 202024 Mar]. Disponível em: <http://revodonto.bvsalud.org/scielo. php? pid=S003472722012000100016\&script=sci_arttext $>$.

Tavares B. Cresce atuação de dentistas nas UTIs brasileiras [online]. Brasília: CEMOI; 2019 [citado 2019 Jan 03]. Disponível em: <https://www.cemoi.com.br/atuacaode-dentistas-nas-utis-muda-parametros-em-hospitaisbrasileiros/>. 
Donatelli L. Coronavírus: qual o papel do cirurgiãodentista na prevenção? [online]. 2020 [citado 2020 Mar 10]. Disponível em: <https://www.cristofoli.com/ biosseguranca/5-coronavirus-qual-o-papel-do-cirurgiaodentista-na-prevencao/>.

Gandra A. Coronavírus limita atendimentos de Odontologia a urgência e emergência [online] [citado 2020 Mar 16]. Disponível em: <https://agenciabrasil. ebc.com.br/saude/noticia/2020-03/coronavirus-limitaatendimentos-de-odontologia-urgencia-e-emergencia>. 